\title{
Investigation of Novel Plant Maerua Shrub (Maerua subcordata) for Cheap and Efficient Bioethanol Production in Kenya
}

\author{
Wesley Rerimoi Kangor ${ }^{1 *}$, Kiplagat Ayabei', Samuel Lutta ${ }^{1}$, Geoffrey Maiyoh ${ }^{2}$ \\ ${ }^{1}$ Department of chemistry and Biochemistry, University of Eldoret, Eldoret, Kenya \\ ${ }^{2}$ Department of Biochemistry and Clinical Chemistry, School of Medicine, Moi University, Eldoret, Kenya \\ Email: *kangor.wesley@yahoo.com
}

How to cite this paper: Kangor, W.R., Ayabei, K., Lutta, S. and Maiyoh, G. (2021) Investigation of Novel Plant Maerua Shrub (Maerua subcordata) for Cheap and Efficient Bioethanol Production in Kenya. Journal of Agricultural Chemistry and Environment, 10, 305-313.

https://doi.org/10.4236/jacen.2021.103019

Received: May 28, 2021

Accepted: July 6, 2021

Published: July 9, 2021

Copyright $\odot 2021$ by author(s) and Scientific Research Publishing Inc. This work is licensed under the Creative Commons Attribution International License (CC BY 4.0).

http://creativecommons.org/licenses/by/4.0/

\begin{abstract}
Bioethanol is an attractive source of energy when compared to fossil fuel. It is renewable and environmentally friendly due to its low toxicity and biodegradability. The first generation bioethanol derived from is limited by the high cost of production of these crops and danger posed to food security. This study investigated the use of wild maerua shrub in production of bioethanol in comparison to cultivated food crops. Fermentation was done using Yeasts $\mathrm{Y} 1, \mathrm{Y} 2$ and $\mathrm{Y} 3$. Yeasts $\mathrm{Y} 1$ and $\mathrm{Y} 2$ were isolated from finger millet malt, while Y3 was the commercial yeast Saccharomyces cerevisiae. Fermented plant samples were distilled, oxidized and analysed at 595nm using UV-Visible spectrophotometer. Statgraphics centurion XVI.I was used for statistical analyses. The concentration $(\mathrm{g} / \mathrm{L})$ was obtained from a formula and converted to $(\mathrm{g} / \mathrm{L})$. The ethanol concentration $(\mathrm{g} / \mathrm{L})$ and productivity $(\mathrm{g} / \mathrm{L} / \mathrm{h})$ were as follows; cassava (64.052 $\pm 0.098 ; 1.334)$, maize ( $66.670 \pm 0.227 ; 1.389)$, sorghum $(62.382 \pm 2.148 \mathrm{~b} ; 1.300)$ and maerua shrub $(61.988 \pm 0.160,1.291)$ which were significantly higher compared to sugarcane molasses $(49.978 \mathrm{~g} / \mathrm{L}, 1.041)$ when fermented by $\mathrm{Y} 2$. Mean ethanol concentration $(\mathrm{g} / \mathrm{L})$ and productivity $(\mathrm{g} / \mathrm{L} / \mathrm{h})$ for plants across all yeasts were comparable $(\mathrm{p}$-value $=0.4239)$. Maerua Shrub should be used as an alternative sugar source for bioethanol production.
\end{abstract}

\section{Keywords}

Maerua Shrub, Bioethanol, Biofuel, Productivity, Fermentation, Feedstock

\section{Introduction}

Biofuels are chemicals that contain energy generated and derived from biomass 
in which they are sustainable and renewable sources. Biofuel includes bioalcohols mainly bioethanol, biodiesel, biogas [1]. Bioethanol is ethyl alcohol produced through biomass conversion via biochemical processes [2]. The bioethanol-gasoline blend is used as a source of energy, also used to synthesize ethyl tertiary butyl ether (ETBE) in which both are blended with gasoline to reduce pollutant levels such as $\mathrm{CO}, \mathrm{NO}_{\mathrm{X}}$ in vehicles [3].

Biofuels are alternative energy sources because they are non-toxic, biodegradable and their combustion releases remarkably less amount of greenhouse gases and particulate matter [4]. Bioethanol is used as transportation fuel in its pure form or mixed with gasoline which enhances octane in gasoline and oxygenated fuel mix reduces air pollution [5]. Bioethanol application in the compressionignition engine is enhanced by blending biodiesel-diesohol which shows good performance especially when a dual fuel operation system is used, a maximum of $80 \%$ ethanol ratio can be attained when loads are increased [6].

Alcohol-based hand sanitizers are prepared using ethanol, isopropyl alcohol and n-propanol with solutions containing alcohol above $60 \% \mathrm{v} / \mathrm{v}$ being most effective in inactivating SARS-CoV-2 also commonly known as COVID-19 [7].

Bioethanol is used as cooking fuel especially by using bioethanol stoves that are currently in the market; this fuel mix reduces air pollution significantly from within the house as compared to fuels such as kerosene as a result use of bioethanol reduces cardiovascular health problems [8].

Greenhouse gas and aerosol emissions are associated with climate change. The use of biodiesel and bioethanol remarkably decrease emitted greenhouse gases from engines. Particulate number and particulate matter emission decrease remarkably when oxygen-containing fuel, blends with gasoline [8].

First generation employ methods that use food crops to produce various forms of biofuels, however, it is associated with many disadvantages such as food insecurity because it competes with food supply unlike other generations [10]. Maerua subcordata is a wild shrub found in arid and semiarid land of East Africa, especially in burned regions of grassland [11]. This plant was used to investigate bioethanol production because it is known to contain high carbohydrate concentration.

Despite being an attractive renewable and environmentally friendly source of energy than fossil fuels, various factors have hindered bioethanol production. First generation bioethanol is expensive because it is produced from food crops, which account for more than half of its cost. In addition, the use of food crops in bioethanol production would cause food insecurity a situation that causes a lack of food and increases their cost further. There is increased demand for alcohol-based sanitizers currently because of COVID-19 disease. The use of lignocellulosic feedstock is challenging due to the high cost of pretreatment despite the fact that they are readily available. Therefore it is necessary to research other non-food crops for bioethanol synthesis. 


\section{Materials and Methods}

Chemicals and reagents used were Potassium dichromate (Griffin \&George), concentrated Sulphuric acid, absolute ethanol (Griffchem Fine chemicals), $\alpha$-amylase enzyme (Loba chemie) and distilled water distilled from University of Eldoret Laboratory.

Finger millet, maize, sorghum, cassava and maerua shrub were collected from Kaplelwo village, Emining division, Baringo County. The samples were collected randomly and also depended on availability, consent of the farmers, maturity and health of the plant.

About $4 \mathrm{~kg}$ of each fresh cassava and maerua shrub tubers were weighed and washed in clean fresh water. Exactly $1 \mathrm{~kg}$ of freshly harvested grains of sorghum and maize, were weighed. About 2 litres sugarcane molasses in plastic container was purchased at an Agrovet in Eldoret town. Exactly $100 \mathrm{~g}$ of standard yeast (Saccharomyces cerevisiae) was supplied by the Agrochemicals Company of Kenya at Muhoroni.

\subsection{Preparation of Samples}

$20 \mathrm{~g}$ of each plant samples were weighed and placed into clean $250 \mathrm{~mL}$ Erlenmeyer flask. The flasks were labelled as; A-maerua shrub, B-cassava, C-sorghum, D-maize and E-molasses. Exactly $120 \mathrm{~mL}$ of distilled water was measured, poured into the flasks containing samples and stirred to soak completely. The level of the mixture was marked, then sample were autoclaved at $121^{\circ} \mathrm{C}$ for 15 minutes [12]. Distilled water was added to the initial mark and cooled to $40^{\circ} \mathrm{C}$. Exactly 1 $\mathrm{g}$ of $\alpha$-amylase enzyme was (in excess) followed by $1 \mathrm{~g}$ of yeasts to each sample resulting in 5\% inoculums size and allowed to ferment. Each flask was covered with aluminium foil secured using a rubber band. They were incubated for 48 hours at $35^{\circ} \mathrm{C}$ which are optimum conditions for fermentation. Figure 1 show the summary of the procedures for processing samples.

The filtrates were distilled using well assembled apparatus with thermostatic heater as source of heat. The temperature was maintained at $85^{\circ} \mathrm{C}$ to extract most of the vapour from the fermentation broth [13].

The distillate was tested for ethanol by adding $1 \mathrm{~mL}$ of potassium dichromate to $1 \mathrm{~mL}$ of $10 \%$ diluted absolute ethanol. The procedure was done using $1 \mathrm{~mL}$ of distillate and $1 \mathrm{~mL}$ of potassium dichromate, heated in water bath for 10 minutes for the colour to develop.

A calibration curve on absorbance against ethanol concentration (\%) v/v was drawn according to modified procedure by [14]. Exactly $0.5 \mathrm{~mL}$ was added to about $4.5 \mathrm{~mL}$ of distilled water so as to dilute it ten folds to lower the concentration to a measurable concentration. Accurately measured $2.0 \mathrm{~mL}$ of the resultant solution was mixed with $2.0 \mathrm{~mL}$ of $0.298 \mathrm{M}$ acidified potassium dichromate solution.

\subsection{Data Analysis}

Descriptive statistics (mean and standard deviations) were used to summarize 


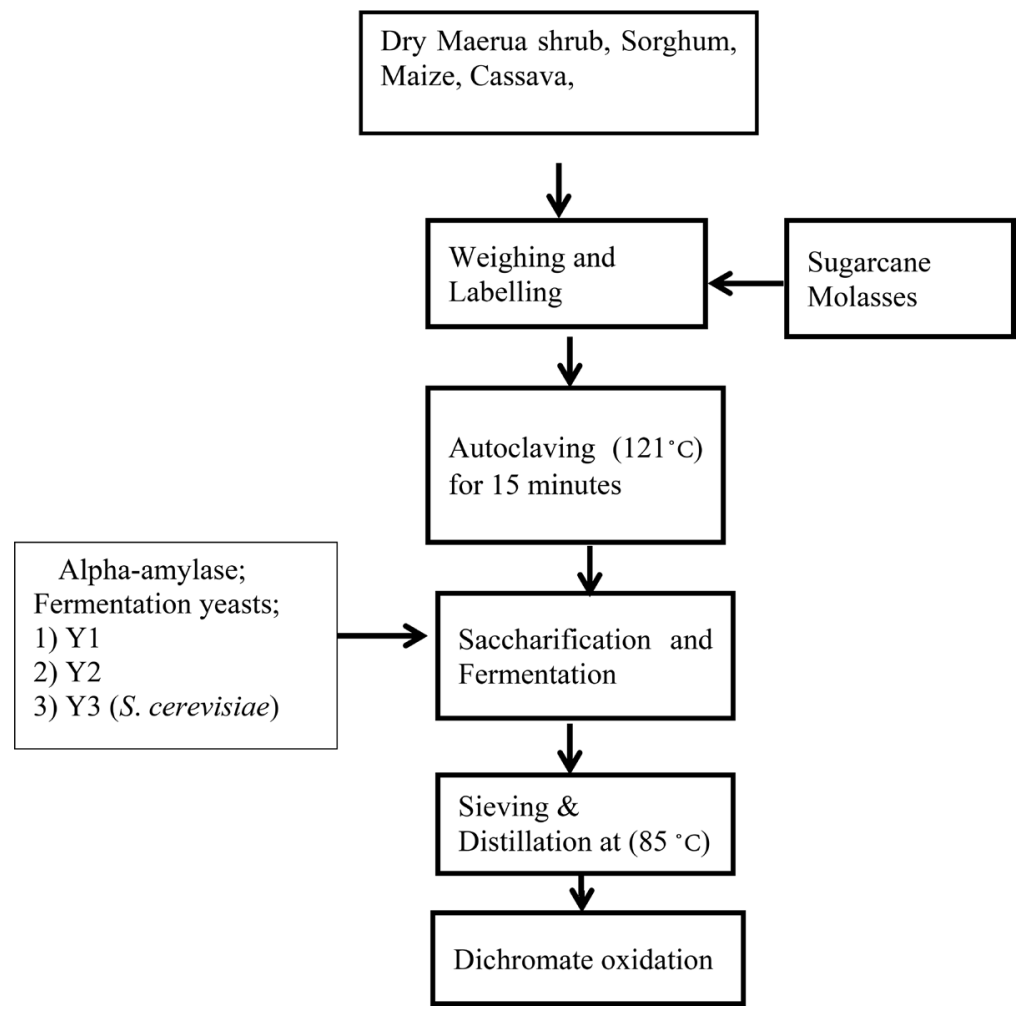

Figure 1. Flow chart on procedures of fermentation and extraction of samples.

ethanol concentration. One-way analysis of variance (ANOVA) was used to determine significant difference in ethanol concentration of maerua shrub, cassava, sorghum, maize and sugarcane molasses. Statgraphics centurion XVII was used to carry out the statistical analyses. LSD-Fishers least significant difference was used.

\section{Results and Discussion}

The green colour of the standard ethanol and samples in potassium dichromate confirms the presence of ethanol in the distillate. Calibration curve was constructed basing on the results obtained by determining absorbance of the standard solution prepared. Dichromate solution was used as blank. A graph was plotted obtaining a straight line. Where $\mathrm{R}^{2}=0.9983$ there was a strong correlation between absorbance and ethanol concentration. Concentration of samples was obtained by substituting $\mathrm{X}$ with absorbance. Ethanol concentration in $(\mathrm{g} / \mathrm{L})$ was obtained by converting percentage ethanol $\mathrm{v} / \mathrm{v}$ in $100 \mathrm{~mL}$ to a liter $(1000 \mathrm{~mL})$ then multiplied by density of ethanol $(0.789 \mathrm{~g} / \mathrm{mL})$. The results were represented using bar graphs as shown in Figure 2 below.

Maerua shrub produced ethanol concentration which is comparable to that of maize $(\mathrm{p}=0.1)$ and sugarcane molasses $(\mathrm{p}=0.4109)$ when fermented with $\mathrm{Y} 1$, however, cassava $(p=0.0061)$ and sorghum produce ethanol concentration that are significantly higher. To the best of our knowledge, there are no other similar studies that have been conducted with Maerua shrub and therefore no data was 


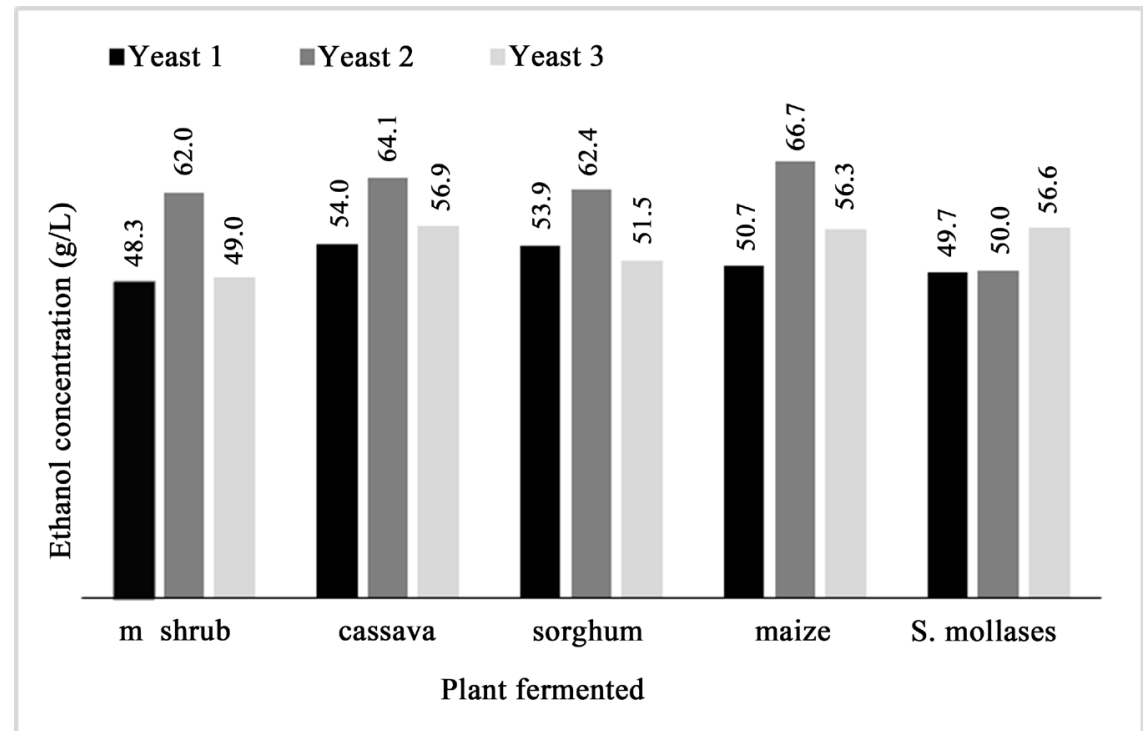

NB: Values represent means of duplicate experiments were determined for significant difference at $\mathrm{p}$ $<0.05$. Mean ethanol concentration $(\mathrm{g} / \mathrm{L})$ and productivity $(\mathrm{g} / \mathrm{L} / \mathrm{h})$ for plants across all yeasts were comparable $(\mathrm{p}$-value $=0.4239, \mathrm{~F}$ ratio $=1.03)$.

Figure 2. Concentration of ethanol concentration $(\mathrm{g} / \mathrm{L})$ produced upon fermentation of the various plants using different yeast strain.

available in the literature to be used for comparison. Nonetheless, we consider our findings to be novel in this regard. Fermentation of plant materials with high glucose concentration has been shown results in proportionately higher ethanol concentration and productivity [15]. Other favourable conditions that determine ethanol yields include carbon source and nitrogen [16]. This could be the reason why sorghum produced higher concentration of ethanol than maize and sugarcane molasses despite the two having higher concentration of reducing sugar than sorghum.

Reference [17] used Saccharomyces cerevisiae, which produced maximum ethanol concentration $106 \mathrm{~g} / \mathrm{L}$ in $24 \mathrm{~h}$ of fermentation, productivity of $4.4 \mathrm{~g} / \mathrm{L} / \mathrm{h}$ which is high than ethanol concentration of sorghum whose value was $(1.30 \mathrm{~g} / \mathrm{L} / \mathrm{h})$. The observed disparity may be attributed to the high concentration of reducing sugar $(250 \mathrm{~g} / \mathrm{L})$ because hydrolysis was done using alpha-amylase and glucoamylase. In the present study only alpha-amylase enzyme was used to hydrolyse starch.

Cassava, maize, sorghum and maerua shrub produced ethanol concentration and productivity which were significantly higher compared to that of sugarcane molasses whose concentration and productivity when fermented using Y2. When $\mathrm{Y} 1$ and $\mathrm{Y} 3$ were used to ferment maize and cassava the results had significant difference compared to that of Y2. Reference [18] obtained ethanol productivity of $1.35 \mathrm{~g} / \mathrm{L} / \mathrm{h}$ when cassava starch was fermented using wild type of $S$. cerevisiae, these results were in agreement to the results obtained using Y2.

Cassava yielded significantly higher ethanol concentration compared to concentration from maerua shrub, sorghum, maize and sugarcane molasses when 
fermented by (Saccharomyces cerevisiae) Y3. Cassava produce high ethanol concentration due to high concentration of reducing sugars, this is supported by [19]. Reference [20] obtained ethanol concentration (30 - $35 \mathrm{~g} / \mathrm{L}$ ), when cassava was fermented for $24 \mathrm{~h}$ using Saccharomyces cerevisiae with complete conversion of sugar. The productivity from these results is $(1.250-1.458 \mathrm{~g} / \mathrm{L} / \mathrm{h})$ which are higher than the results from Y3 ( $S$. Cerevisiae). The reason for the difference is the complete conversion of sugar to ethanol by the yeast.

Sugarcane molasses produced lower ethanol level compared to maize, cassava and sorghum, the high concentration of reducing sugar could have interfered with yeast cellular physiology therefore reducing fermentation efficiency. The lower ethanol concentration from sugarcane molasses is caused by its lower nitrogen concentration than concentration of other plants it contains $(0.61 \% \mathrm{w} / \mathrm{w})$ obtained by and does not contain lipids which are important substances as amino acid. Amino acids provide raw material for energy generation, biosynthesis of structural or defensive compounds against abiotic and biotic stress, while the role of lipids are adaptation to stress, membrane structure and signalling molecule in yeasts [21].

Maerua shrub should be used in production of cheaper bioethanol because of producing high ethanol concentration and productivity when fermented by $\mathrm{Y} 2$, this result has insignificant difference compared to the concentration from maize, cassava, and sorghum. These crops are food sources therefore the cost of production for bioethanol is higher than the cost of using maerua shrub.

The cost of raw materials considerably affects the sustainability of bioethanol production [22]. It implies the low cost feedstock such maerua shrub contribute lower percentage of the total cost an idea supported by [23], while the food crops contribute a higher cost because of high demand for food, consequently increasing bioethanol production cost and food shortage. Production of bioethanol from sugarcane molasses is also costlier due to its use as food and animal feed.

Maerua shrub is plant that can grow on marginal lands and produce bioethanol is advantageous because it ensure food security and does not compete with food crops for arable fertile lands an idea supported by [24].

\section{Conclusion and Recommendations}

Based on our findings, Maerua shrub showed ethanol productivity that is comparable to that of cassava, sorghum, sugarcane molasses and maize, therefore the plant can be used to substitute these food crop plants. Bioethanol produced from maerua shrub would enhance food security since it is a non-food plant and also translate to lower costs of production. Further, the commercial farming of this plant by farmers is highly recommended as it will enhance the cultivation of arid and semi-arid land because of its resistance to drought.

\section{Acknowledgements}

We send our thanks to technicians of University of Eldoret for their support, al- 
so Mr. Macharia of Agrochemicals Company of Kenya for his assistance.

\section{Conflicts of Interest}

The authors declare no conflicts of interest regarding the publication of this paper.

\section{References}

[1] Abbas, A.R. and Al-Zuhairi, F. (2020) Biofuels (Bioethanol, Biodiesel, and Biogas) from Lignocellulosic Biomass: A Review. Journal of University of Babylon for Engineering Sciences, 28, 202-215. https://www.journalofbabylon.com/index.php/JUBES/article/view/2948

[2] Tran, T.T., Le, T.K.P., Mai, T.P. and Nguyen, D.Q. (2019) Bioethanol Production from Lignocellulosic Biomass. In: Yun, Y., Ed., Alcohol Fuels-Current Technologies and Future Prospect, IntechOpen, London.

[3] Lelieveld, J., Klingmüller, K., Pozzer, A., Burnett, R.T., Haines, A. and Ramanathan, V. (2019) Effects of Fossil Fuel and Total Anthropogenic Emission Removal on Public Health and Climate. Proceedings of the National Academy of Sciences of the United States of America, 116, 7192-7197. https://doi.org/10.1073/pnas.1819989116

[4] Nahar, K. and Sunny, S.A. (2020) Duckweed-Based Clean Energy Production Dynamics (Ethanol and Biogas) and Phyto-Remediation Potential in Bangladesh. Modeling Earth Systems and Environment, 6, 1-11. https://doi.org/10.1007/s40808-019-00659-y

[5] Wibowo, C.S., Nugroho, Y., Sugiarto, B., Adian, F., Masuku, M. and Maymuchar (2020) The Optimization Performance of Mixed Fuel Gasoline RON 88, 92, 98 with Bioethanol on Spark Ignition Engine. International Journal of Engineering Research and Technology, 9, 989.

[6] Han, J., Somers, L.M.T., Cracknell, R., Joedicke, A., Wardle, R. and Mohan, V.R.R. (2020) Experimental Investigation of Ethanol/Diesel Dual-Fuel Combustion in a Heavy-Duty Diesel Engine. Fuel, 275, Article No. 11786.

https://doi.org/10.1016/j.fuel.2020.117867

[7] Golin, A.P., Choi, D. and Ghahary, A. (2020) Hand Sanitizers: A Review of Ingredients, Mechanisms of Action, Modes of Delivery, and Efficacy against Coronaviruses. American Journal of Infection Control, 48, 1062-1067.

https://doi.org/10.1016/j.ajic.2020.06.182

[8] Olopade, C.O., Frank, E., Bartlett, E., Alexander, D., Dutta, A., Ibigbami, T., Adu, D., Olamijulo, J., Arinola, G., Karrison, T. and Ojengbede, O. (2017) Effect of a Clean Stove Intervention on Inflammatory Biomarkers in Pregnant Women in Ibadan, Nigeria: A Randomized Controlled Study. Environment International, 98, 181-190. https://doi.org/10.1016/j.envint.2016.11.004

[9] Liu, H., Wang, X., Zhang, D., Dong, F., Liu, X., Yang, Y. and Zheng, Z. (2019) Investigation on Blending Effects of Gasoline Fuel with N-Butanol, DMF, and Ethanol on the Fuel Consumption and Harmful Emissions in a GDI Vehicle. Energies, 12, Article No. 1845. https://doi.org/10.3390/en12101845

[10] Kurowska, K., Marks-Bielska, R., Bielski, S., Kryszk, H. and Jasinskas, A. (2020) Food Security in the Context of Liquid Biofuels Production. Energies, 13, Article No. 6247. https://doi.org/10.3390/en13236247

[11] Strauch, M.A. and Eby, S. (2012) The Influence of Fire Frequency on the Abundance of Maerua subcordata in the Serengeti National Park, Tanzania. Journal of Plant 
Ecology, 5, 400-406. https://doi.org/10.1093/jpe/rts008

[12] Fitriana, F., Sunarno, S., Syarif, A., Karyana, M., Rosana, Y. and Moehario, H. (2019) A New Modified Medium for Simultaneous Cystinase and Elek Tests of Bacteria Causing Diphtheria. Bali Medical Journal, 8, 334-340. https://doi.org/10.15562/bmj.v8i1.1231

[13] Negera T. (2017) Isolation and Characterization of Ethanol, Sugar and Thermo Tolerant Yeast Isolates in Ethiopia. International Journal of Research Studies in Biosciences (IJRSB), 5, 4-10. https://doi.org/10.20431/2349-0365.0508002

[14] Andrea, C. (2015) Quantitative Analysis of Alcoholic Drinks. Use of Calibration Curve Method to Determine the Alcoholic Degree of Samples of Paesanella, a Distillate of the Family of Grappa. World Journal of Chemical Education, 3, 70-73. https://doi.org/10.12691/wjce-3-3-3

[15] Songdech, P., Ruchala, J., Semkiv, M.V., Jensen, L.T., Sibirny, A., Ratanakhanokchai, K. and Soontorngun, N. (2020) Overexpression of Transcription Factor ZNF1 of Glycolysis Improves Bioethanol Productivity under High Glucose Concentration and Enhances Acetic Acid Tolerance of Saccharomyces cerevisiae. Biotechnology Journal, 15, e1900492. https://doi.org/10.1002/biot.201900492

[16] Mezenova, O.Y., Keshtkar, S., Kulaev, K.T., Danshina, S.D. and Romiani (2020) The study of Ethanol Production by New Strain of Yeasts, Hanseniaspora opuntiae MK 460485, Investigation of Its Ethanol Production in Presence of Different Carbon and Nitrogen Sources and Optimal Conditions. Journal of Critical Reviews, 7, 498-505. https://doi.org/10.31838/jcr.07.04.94

[17] Barcelos, C.A., Maeda, R.N., Betancur, G.J.V. and Pereira Jr., N. (2011) Ethanol Production from Sorghum Grains [Sorghum bicolor (L.) Moench]: Evaluation of the Enzymatic Hydrolysis and The Hydrolysate Fermentability. Brazilian Journal of Chemical Engineering, 28, 597-604. https://doi.org/10.1590/S0104-66322011000400005

[18] Choi, G.W., Um, H.J., Kim, Y., Kang, H.W., Kim, M., Chung, B.W. and Kim, Y.H. (2010) Isolation and Characterization of Two Soil Derived Yeasts for Bioethanol Production on Cassava Starch. Biomass and Bioenergy, 34, 1223-1231. https://doi.org/10.1016/j.biombioe.2010.03.019

[19] Suryawanshi, O.P., Khokhar, D. and Patel, S. (2018) Effect of Different Pre-Treatment Methods on Reducing Sugar of Rice Substrate to Enhance the Ethanol Yield. International Journal of Current Microbiology and Applied Sciences, 7, 2715-2733. https://doi.org/10.20546/ijcmas.2018.703.314

[20] Hariharan, H., Joshy, E.N., Sajeevan, K. and Moneyraj, K. (2020) Bioethanol Production from Sweet Potato and Cassava by Simultaneous Saccharification and Fermentation. In: Sivasubramanian, V., Pugazhendhi, A. and Moorthy, I., Eds., Sustainable Development in Energy and Environment, Springer Proceedings in Energy, Springer, Singapore, 13-23. https://doi.org/10.1007/978-981-15-4638-9_2

[21] Chen, Y., Zeng, L., Liao, Y., Li, J., Zhou, B., Yang, Z. and Tang, J. (2020) Enzymatic Reaction-Related Protein Degradation and Proteinaceous Amino Acid Metabolism during the Black Tea (Camellia sinensis) Manufacturing Process. Foods, 9, Article No. 66. https://doi.org/10.3390/foods9010066

[22] Susmozas, A., Martín-Sampedro, R., Ibarra, D., Eugenio, M.E., Iglesias, R., Manzanares, P. and Moreno, A.D. (2020) Process Strategies for the Transition of 1 G to Advanced Bioethanol Production. Processes, 8, Article No. 1310. https://doi.org/10.3390/pr8101310

[23] Pandey, K., Shrestha, B., Khanal, S., Adhikari, D. and Kunwar, C.B. (2019) Ad- 
vances in Maize-Based Bioethanol Production and Its Prospects in Nepal. International Journal of Graduate Research and Review, 5, 122-130.

[24] Mehmood, M.A., Ibrahim, M., Rashid, U., Nawaz, M., Ali, S., Hussain, A. and Gull, M. (2017) Biomass Production for Bioenergy Using Marginal Lands. Sustainable Production and Consumption, 9, 3-21. https://doi.org/10.1016/j.spc.2016.08.003 